\title{
The Development of Vocational Calling, Identity, and Faith in College Students: A Preliminary Study of the Impact of Study Abroad
}

\section{Cindy Miller-Perrin \\ Pepperdine University}

\section{Don Thompson}

Pepperdine University

Living and learning in another country, primary conditions of the study abroad experience, are commonly associated with two fundamental outcomes. The first outcome is an increase in external connections, manifested through an increased ability to converse in another language and an increased understanding and sensitivity to another culture. The second outcome is an internal redirection, a deepening sense of identity and self-awareness. Joseph Campbell has much to say about both of these elements, as he writes about the importance of journey. About the external dimension he says: "And this is the basic mythological problem: Move into a landscape. Find the sanctity of that land. And then there can be a matching of your own nature with this gorgeous nature of the land. It is the first essential adaptation" (Campbell, 2003, p.7). Campbell notes, however, that external change is not legitimate unless it is accompanied by internal change.

Study abroad experiences and their relationship to external educational goals have been studied extensively in terms of its effects on enhancing foreign language acquisition as well as cultural awareness and intercultural relationships. In addition, there is growing evidence of the importance of study abroad programs on other external higher education goals such as "high-impact" practices that engage college students to a greater extent than traditional classroombased instructional experiences. The National Survey on Student Engagement (NSSE), for example, recently described evidence of the most significant activities that impact student success in and beyond the college years (Kuh, 2008). Study abroad was one of these "high impact activities," identified as affecting such areas as academic achievement, engagement in educationally purposeful activities, satisfaction, acquisition of desired knowledge, skills and competencies, 
persistence, attainment of educational objectives, knowledge of human cultures and the physical/natural world, intellectual and practical skills, personal and social responsibility, deep/integrative learning, and post-college performance (Gonyea, Kinzie, Kuh and Laird, 2008).

In contrast, research addressing higher education goals associated with internal effects have not yet been fully explored in terms of their connection to study abroad experiences. The current study focuses on several elements of personal growth and internal development that are particularly salient during the college years. The first element is students' developing sense of life purpose, or vocational calling. Questions about life meaning and purpose often surface during the college years as students consider issues associated with both faith beliefs and career options. For the purpose of the current study, we draw from the conceptual literature on vocation and life purpose and define vocational calling somewhat broadly, as sacred lifework, which includes any human activity that gives meaning, purpose, and direction to life. In discerning vocational calling, then, the question is this: "What am I supposed to do with my life?" or "What am I living for?" Although little attention has been given to this area of personal growth, it is of significant interest to many who study college student development. Indeed, many authors have argued that higher education can, and should, play a central role in helping students to discover and pursue their vocational callings (Crosby, 2004; Dalton, 2001).

The second element is students' developing sense of faith and spirituality. College students are increasingly interested in matters of religion, faith, and spirituality as it relates to their life purpose and sense of personal wholeness. Studies on beliefs and values among college students (Higher Education Research Institute, 2005), research projects focusing on youth and religion (Smith \& Denton, 2005), and the surge in enrollments in religiously affiliated colleges and universities (Riley, 2004) evidence a movement toward a greater focus on faith, spirituality, and religion in the academy. In addition, Paloutzian, Richardson, and Rambo (1999) suggest that religion is the only area in which one encounters commitment to an ultimate concern or purpose, and as a result, might inspire the development of life purpose or a sense of vocation. There have been numerous studies that have researched the relationship between faith and life purpose, and findings indicate a positive relationship between life purpose and various aspects of faith, such as mysticism (Byrd, Lear, \& Schwenka, 2000), spiritual experiences (Kass, Friedman, Leserman, Zuttermeister, \& Benson, 1991), religious conversion (Paloutzian et al., 1999), and spiritual strivings (Emmons, 2005).

The third and final element of student growth examined in this study is students' identity development. We believe that academic study abroad 
contributes to helping students gain their sense of identity which in turn contributes to both faith development and a deeper sense of vocational calling. Our work is an attempt to see evidence of aspects of the "hero journey," as described by Joseph Campbell (2003) and Richard Rohr (1994), within the college experience of study abroad. The purpose of this journey is twofold-first, for the hero to grow up and move into adulthood, realizing his/her "name" and identity, and second, to discover his/her purpose in life (i.e., what they love most and where that love meets the world's needs). This journey involves three key phases: a) separation and departure, b) exploration and discovery, and c) return. These milestones occur, for the most part, when a young adult goes away to college, ultimately bringing about the sojourner's self-discovery and sense of vocational calling. Moreover, these events are found compressed and accentuated when that young person leaves their homeland to live and study in another country and culture. Although to date we know of no studies linking identity development to life purpose or vocational calling, there are a significant number of studies that tie the development of identity to the maturation of religious faith (e.g., Fowler, 1981; Lindholm, 2006; Maslow, 1999).

The current study is a response to the call for greater understanding of the interior aspects of student development, as bound to significant experiences in the life of the college student, particularly the increasingly popular experience of study abroad. Our approach to gaining this understanding is to provide empirical evidence of the ways in which an international living and learning experience significantly enhances college student development in the areas of identity, faith, and vocational calling. Accordingly, our research hypothesis is that students who participate in study abroad programs experience significantly greater changes in faith, vocational calling, and identity development than do students who do not participate in such programs.

\section{M e t h od}

\section{Participants}

The sample for the current study was derived from a random sample of 300 students from the 2002 entering class of a private, Christian, liberal arts university in Southern California participating in a longitudinal study on the development of faith, identity, and life purpose. The sample consisted of 74 students ranging in age from 18-22 years and included 28 males and 46 females. Participants were predominantly Caucasian (70\%), with other ethnicities also present (7\% Asian, 8\% Latino, 1\% African American, and 14\% other). The majority of participants reported Protestant (65\%) as their religious affiliation and approximately half (47\%) reported parental income greater than $\$ 100,000$. 


\section{Dependent Variable Measures}

Identity Status. An adapted version of the Objective Measure of Ego-Identity Status (OMEIS; Adams, Shea, \& Fitch, 1979) was used to assess identity. The OMEIS is based on James Marcia's (1966) theory of identity formation and provides a self-report alternative to the clinical interview. It has been used in a multitude of studies investigating the ego-identity status paradigm (Adams, 1998). Twenty studies investigating the reliability of the OMEIS indicated moderate to strong consistency between items $(\alpha=0.66)$, and evidence for consistency across multiple test administrations ( $r=0.76$ ) (Adams, 1998).

The OMEIS was used to assign scores for participants on four identity status scales: diffusion, foreclosure, moratorium, and achievement. The diffusion identity status describes individuals who have not explored alternative values, beliefs, and roles and have not established ideological commitments. The foreclosure status describes individuals who have made identity commitments but have not explored alternatives. They generally have adopted commitments from others and have not individualized these commitments. The moratorium identity status describes individuals who are in the midst of exploring and experimenting with various ideologies, values, and roles and have not yet made stable identity commitments. Finally, the achievement identity status describes individuals who have made stable identity commitments after having explored various alternatives. (see Appendix I for sample OMEIS questions and subscales.)

Faith Surveys. Two faith inventories were created for the current study in order to obtain a comprehensive assessment of the construct of faith. Together these measures tap the important dimensions of faith identified in Wulff's (1997) review of research in the field of psychology of religion. In an effort to capture the complexity inherent in the construct, faith was defined along two dimensions: faith attitudes and faith experiences. Faith attitudes include how important faith is to the individual, how strong the individual's beliefs are, and to what extent the individual integrates faith into his or her daily life. Faith experiences include a behavioral component as well as an affective component. The behavior component consists of the nature of an individual's religious activities, both in public and private contexts. The affective component consists of the individual's experience of spiritual feelings. These dimensions of faith are consistent with Wulff's (1997) analysis of the main references in the literature identified with faith including the presence of: motivation and commitment to a supernatural power, affective states associated with a supernatural power, and behavioral acts carried out in reference of the supernatural power.

The Faith Attitude Survey (FAS) is a 13-item inventory that includes three subscales that assess: the extent of a participant's personal conviction to his or 
her religious beliefs (Strength of Beliefs; $\alpha=0.73$ ), the degree to which faith is important to the participant (Importance of Faith; $\alpha=0.89$ ), and the extent to which faith is integrated into the various components of the participant's life (Life Application of Faith; $\alpha=0.92$ ). Participants responded to items using a 5-point Likert scale ranging from "strongly disagree" to "strongly agree." See Appendix II for an overview of the FAS subscales with sample items.

The Faith Experience Survey (FES) is a 9-item inventory that includes two subscales that assess: the frequency with which participants engage in various public and private religious activities (Religious Behavior; $\alpha=0.75$ ) and the nature of participant's spiritual feelings (Spiritual Feelings; $\alpha=0.87$ ). Participants responded to items by indicating how frequently they experience various religious behaviors and feelings, such as "never," "once a week," or "one or two times per year," etc. See Appendix II for an overview of the FES subscales with sample items.

Vocational Calling Survey (VCS). An additional measure was created for the current study in order to obtain a brief assessment of the construct of life purpose. We defined life purpose in a Christian context and relied on the conceptual literature on vocational calling. Whereas the secular perspective generally defines vocation as work, career, or occupation, the Christian perspective generally views vocation in a spiritual context, as a charge to love and serve others with Godgiven gifts and talents (Buechner, 1993; Farnham, Gill, McLean, \& Ward, 1991; Hardy, 1990; Raines \& Day-Lower, 1986). We conceptualize vocational calling somewhat broadly to include any human activity that gives meaning, purpose, and direction to life. The VCS, therefore, included two subscales: one 6-item subscale assessing participants' general sense of life purpose and vocational calling, as well as their awareness of their gifts and talents $(\alpha=0.79)$, and one 3-item subscale assessing participants' commitment to serving others either generally or through their career choice $(\alpha=0.69)$. See Appendix II for sample items measuring sense of life purpose and calling and commitment to serving others.

\section{Independent Variable - Study Abroad Participation}

Our institution has a 45-year history of offering international learning experiences to its undergraduate population. At present, nearly $60 \%$ of undergraduates participate in at least one semester of study abroad. Furthermore, approximately $65 \%$ of university faculty members participate in these programs, serving as visiting faculty who live and learn alongside the students. We currently offer year round and single semester learning opportunities in twelve countries. For the majority of programs, students apply during their first year and then study abroad during their sophomore year, following which they re-assimilate into the home campus culture. 


\section{Procedure}

Three hundred prospective participants were randomly selected from the 2002 entering class of a private, Christian, liberal arts university in southern California. Prospective participants were selected using a stratified random sampling technique to insure equal numbers of males and females. Students were sent a letter inviting them to complete a web-based survey during the spring of their first year of study at the university. Participants were then surveyed every spring each of their four years as undergraduates. Those who chose to participate provided demographic information and then completed the dependent measures in the following order: OMEIS, FAS, FES, LPS. The survey materials required approximately 30 minutes to complete. As an incentive, participants received one hour of 'convocation credit' for participating in the study. Response rates across the four years ranged from $64-83 \%$.

For the purpose of the present study, 99 students who completed the survey during both their first-year and senior year were considered for selection in order to compare scores on the dependent measures before students attended an international program (First-year score) to scores following participation in such a program (Senior score). Of these students, $60 \%$ had participated in an international program. A subsample of 37 college students who participated in an international program experience (the IP Group) was matched on age and gender to 37 college students who did not participate in such a program (the No IP Group).

\section{Results}

\section{Preliminary Group Comparisons}

We conducted chi-square analyses of the responses of the IP and No IP Groups on demographic information and the results are shown in Table 1. Results indicated no significant group differences, suggesting that group differences obtained in subsequent group comparisons were not due to group differences in socioeconomic status, religion, or ethnicity.

\section{Group Comparisons on Faith Measures}

We conducted a 2 X 2 (Group X Time) repeated-measures ANOVA on participants' First-Year and Senior scores for each faith measure. Table 2 presents the means and standard deviations by IP Group for both the First-Year and Senior assessment periods. Significant Time effects were observed for both Importance of Faith, $F(1,72)=7.41, p<.01$, and Religious Behavior, $F(1,72)=$ $5.73, p<.03$. These findings suggest that student attitudes about the importance 
Table 1. Percentage of Students in International Program Groups across Demographic Variables

\begin{tabular}{|c|c|c|}
\hline Demographic Variable & $\begin{array}{l}\text { IP } \\
\text { Group }\end{array}$ & $\begin{array}{l}\text { No IP } \\
\text { Group }\end{array}$ \\
\hline \multicolumn{3}{|l|}{ Parental Income } \\
\hline$<\$ 40,000$ & 14 & 19 \\
\hline$\$ 40,001-\$ 70,000$ & 22 & 27 \\
\hline$\$ 70,001-\$ 100,000$ & 16 & 14 \\
\hline$\$ 100,001-\$ 130,000$ & 11 & 19 \\
\hline$>\$ 130,000$ & 37 & 21 \\
\hline
\end{tabular}

\section{Ethnicity}

$\begin{array}{lll}\text { African American } & 0 & 8 \\ \text { Asian } & 11 & 11 \\ \text { Caucasian } & 78 & 60 \\ \text { Latino } & 11 & 16 \\ \text { Other } & 0 & 5\end{array}$

$\begin{array}{lll}\text { Religion } & & \\ \text { Catholic } & 11 & 16 \\ \text { Hindu } & 0 & 3 \\ \text { Jewish } & 3 & 0 \\ \text { Protestant } & 78 & 51 \\ \text { Other } & 8 & 30\end{array}$

of their faith as well as the frequency of their religious behavior decreased from their first-year of college to their senior year regardless of whether they studied abroad (see Table 2). A marginally significant Group X Time interaction effect was observed, however, for

Application of Faith scores, $F(1,72)=3.10, p<.09$ suggesting that application of faith scores increased over time for students who studied abroad but decreased over time for students who did not study abroad.

\section{Group Comparisons on Vocational Calling Measures}

We conducted a 2 X 2 (Group X Time) repeated-measures ANOVA on participants' First-Year and Senior scores for each vocational calling measure. Table 3 presents the means and standard deviations by IP Group for both the First-Year and Senior assessment periods. Significant Group X Time interactions were observed for both Sense of Life Purpose, $F(1,72)=4.92, p<.04$, and Service to Others, $F(1,72)=7.68, p<.01$ (see Table 3 ). These findings suggest that sense of life purpose and commitment to serving others increased over time for students who studied abroad but decreased over time for students who did not study abroad. 
Table 2. Means and Standard Deviations for Faith Measures for IP Groups across Measurement Periods

\begin{tabular}{|l|l|l|l|l|l|l|l|l|l|}
\hline \multicolumn{4}{c}{ First } & \multicolumn{1}{c}{ Year } & Senior & \multicolumn{1}{l}{ Year } \\
\hline $\begin{array}{l}\text { Faith } \\
\text { Measure }\end{array}$ & IP & IP & No IP & $\begin{array}{l}\text { No } \\
\text { IP }\end{array}$ & IP & IP & No IP & $\begin{array}{l}\text { No } \\
\text { IP }\end{array}$ \\
\hline & $\mathrm{M}$ & SD & M & SD & M & SD & M & SD \\
\hline $\begin{array}{l}\text { Belief } \\
\text { Strength }\end{array}$ & 23.16 & 4.83 & 23.11 & 3.41 & 23.16 & 4.15 & 22.68 & 4.18 \\
\hline $\begin{array}{l}\text { Faith } \\
\text { Importance }\end{array}$ & $7.89 \mathrm{a}$ & 2.69 & $7.27 \mathrm{a}$ & 3.02 & $8.76 \mathrm{~b}$ & 1.42 & $8.35 \mathrm{~b}$ & 1.69 \\
\hline $\begin{array}{l}\text { Faith } \\
\text { Application }\end{array}$ & 18.81 & 5.22 & 19.51 & 4.14 & 19.70 & 4.68 & 18.19 & 4.84 \\
\hline $\begin{array}{l}\text { Religious } \\
\text { Behavior }\end{array}$ & $28.94 \mathrm{a}$ & 7.75 & $27.23 \mathrm{a}$ & 7.99 & $25.83 \mathrm{~b}$ & 8.25 & $24.97 \mathrm{~b}$ & 9.23 \\
\hline $\begin{array}{l}\text { Spiritual } \\
\text { Feelings }\end{array}$ & 11.82 & 3.57 & 12.60 & 4.11 & 11.89 & 4.20 & 11.67 & 4.08 \\
\hline
\end{tabular}

Note: Means with different subscripts differ significantly at $p<.05$.

\section{Group Comparisons on Identity Measures}

We conducted a 2 X 2 (Group X Time) repeated-measures ANOVA on participants' First-Year and Senior scores for each identity measure. Table 4 presents the means and standard deviations by IP Group for both the First-Year and Senior assessment periods. A significant Time effect was observed for Foreclosure scores, $\mathrm{F}(1,72)=9.37, \mathrm{p}<.01$, suggesting that students' Foreclosure scores decreased from their first year of college to their senior year regardless of whether or not they studied abroad (see Table 4). A marginally significant Group X Time interaction was observed, however, for Achievement scores, $F(1,72)=3.68$, $p$ $<.07$, suggesting that achievement scores increased over time for students who studied abroad but decreased slightly for those who did not study abroad.

Table 3. Means and Standard Deviations for Vocational Calling Measures for IP Groups across Measurement Periods

\begin{tabular}{|c|c|c|c|c|c|c|c|c|}
\hline \multicolumn{5}{|c|}{ First Year } & \multicolumn{4}{|c|}{ Senior Year } \\
\hline Vocation & IP & & No IP & & IP & & No IP & \\
\hline & M & SD & M & SD & M & SD & $\mathrm{M}$ & SD \\
\hline $\begin{array}{l}\text { Sense of } \\
\text { Life } \\
\text { Purpose } \\
\text { and Calling }\end{array}$ & $21.38 a$ & 4.14 & $23.16 a$ & 3.69 & $23.57 b$ & 4.94 & $22.54 b$ & 5.25 \\
\hline $\begin{array}{l}\text { Service to } \\
\text { Others }\end{array}$ & $11.24 \mathrm{a}$ & 2.43 & $12.40 a$ & 2.74 & $12.60 \mathrm{~b}$ & 2.60 & $11.97 \mathrm{~b}$ & 2.60 \\
\hline
\end{tabular}

Note: Means with different subscripts differ significantly at $p<.05$. 
Table 4. Means and Standard Deviations for Identity Measures for IP Groups across Measurement Periods

\begin{tabular}{|c|c|c|c|c|c|c|c|c|}
\hline & \multicolumn{4}{|c|}{ First Year } & \multicolumn{4}{|c|}{ Senior Year } \\
\hline \multirow{2}{*}{$\begin{array}{l}\text { Identity } \\
\text { Measure }\end{array}$} & \multicolumn{2}{|l|}{ IP } & \multicolumn{2}{|l|}{ No IP } & \multicolumn{2}{|l|}{ IP } & \multicolumn{2}{|l|}{ No IP } \\
\hline & M & SD & $\mathrm{M}$ & SD & $\mathrm{M}$ & SD & $\mathrm{M}$ & SD \\
\hline Diffusion & 19.95 & 7.02 & 19.05 & 6.12 & 17.69 & 6.74 & 18.08 & 4.07 \\
\hline Foreclosure & $19.00 \mathrm{a}$ & 6.75 & $17.51 \mathrm{a}$ & 6.42 & $15.94 b$ & 8.12 & $15.32 \mathrm{~b}$ & 5.89 \\
\hline Moratorium & 22.44 & 6.96 & 23.14 & 6.38 & 22.44 & 7.44 & 21.22 & 5.68 \\
\hline Achievement & $29.04 a$ & 4.29 & $31.63 b$ & 4.67 & 31.25 & 5.93 & 31.03 & 4.85 \\
\hline
\end{tabular}

Note: Means with different subscripts differ significantly at $p<.05$.

\section{D iscussion}

Our original research hypothesis stated that students who study abroad will experience significantly greater developmental change in faith, vocational calling, and identity development compared to students who do not study abroad. Our findings suggest that many of these changes, in some fashion, do occur. First, our findings indicate that students reported that the importance of their

faith and their practice of religious behavior both decreased from their first year to their senior year, regardless of whether or not they studied abroad. These findings are consistent with previous findings from Bryant \& Astin (2008), who demonstrated that college students experience spiritual struggle, including disillusionment with their religious upbringing and subsequently became disenchanted with religious practice. In addition, their research provided evidence that college students feel unsettled about matters such as evil, suffering, and death, causing them to question the value of their personal faith. Bryant \& Astin point to several factors that affect this spiritual struggle, including students' encountering events that threaten their customary state of being. Other researchers, such as Lindholm (2006), have discovered that many students develop religious skepticism and distrust of organized religion over their college years. This decrease in the importance of faith and religious practice are no doubt due to the intellectual challenges present in the college experience, wherein exposure to religious diversity and to other worldviews can contribute to challenges to students' beliefs and religious practice systems. Our findings are consistent with this and similar research that present evidence of the disengagement that some college students may experience with regard to their faith or religious heritage.

In contrast, our findings suggest that the application of faith to daily living and decision-making increased for students who studied abroad and decreased for those students who did not study abroad, supporting our original hypothesis. This 
difference may be attributable to external factors that students encounter during study abroad that challenge their faith assumptions and force them to commit to their application. Students who study overseas, for example, may be more inclined to encounter day-to-day circumstances that push them to rely on their faith in order to deal with the challenges of living in another culture. Faith may serve as one of their first coping mechanisms in situations where they encounter doubts, confusion, and the unknown of living abroad. Subsequently, they discover an invaluable, readily available inner resource that provides them a means of sustaining and informing their day-to-day living. Other researchers have found evidence of the powerful influence of religious coping in stressful situations (Pargament, Smith, Koenig, \& Perez, 1998).

Also in support of our research hypothesis, the understanding of vocational calling, and having the inclination to serve others, were both significantly affected by a study abroad experience. Students' sense of vocational calling and desire to serve others increased from the first year to the senior year for those who studied abroad whereas students' sense of life purpose and desire to serve others decreased for those who did not study abroad. Research on life purpose, such as the work of Wong \& Fry (1998), suggests that life transitions and experiences that lead to positive relations with others will frequently contribute to maturation in both sense and application of life purpose. Other authors, such as Damon, Menon, \& Bronk (2003) argue that loss of a sense of life purpose is frequently associated with self-absorption and an inability to hold a larger perspective of place in the world. Therefore, we believe that a reason that the study abroad experience contributes positively to vocational calling is the presence of a significant two-fold effect. Students who study abroad are exposed to a larger world, by virtue of their living and learning in a culture that is foreign to their upbringing, and these same students, in an effort to find their personal moorings, often seek peer and older adult mentors as well as membership in new social communities during their study abroad. The combination of these two experiences may be the reason that vocational maturity increases. International study provides an external environment that challenges students' thinking about the world and about themselves, and it also may provide a mechanism for students to recover from these challenges and grow stronger in a sense of certainty of life direction and in resolve to serve others.

Finally, our research demonstrates some of the potential effects of study abroad on identity development. First, the significant decrease in foreclosure scores that were observed for all students in our sample is consistent with the work of Honess, Yardley, and Yardley-Matwiejczuk (1987), who argue that this identity status naturally decreases in young adults over time. As students grow 
and develop over time, they gain a greater sense of ownership over their own values and beliefs rather than simply adopting those of influential authority figures. In terms of identity achievement, significant increases were observed for the study abroad students but not those students who did not study abroad. These findings are due, in part, to the fact that achievement identity scores were significantly higher in students not attending an international program compared to those that did attend, during the first year assessment period. The changes in the international program group on achievement identity, however, is interesting because it ties to several phenomena cited by Honess and colleagues (1987) as well as with the work of Meeus, Iedema, Helsen and Vollebergh (1999). These phenomena include the presence of time-limited crises that force students to reflect on their sense of self, and significant educational events and experiences that trigger an identity status transition. We believe that these same factors are present in the international study experience, largely in the form of the semester or year-long limits of the study abroad experience, travel in another country and the attendant exposure to other cultures, and the opportunity to be away from the familiarities of home, forcing students to reflect on their sense of self.

Consistent with the work of Geertz (1973), there are a number of cultural universals and transferable implications of this research for the educational work of faculty, students, and co-curricular professionals. First, our findings are consistent with recommendations made by Richard Light (2001), suggesting that students should seek to participate in situations in college life where religious diversity may be found, as these experiences force the examination of personal beliefs and values in a healthy way, and enhance respect for others' views. Learning to embrace cultural, spiritual, and intellectual diversity and conflict will broaden students' horizons and deepen their sense of place in the world. Indeed, if we are to be citizens of the world, we must heed the words of Martha Nussbaum (1997, p. 32): "There is no more effective way to wake pupils up than to confront them with difference in an area where they had previously thought their own ways neutral, necessary, and natural. [...] Socratic inquiry mandates pluralism." And what better way than to "confront" our students with other perspectives, other ways of knowing, and other cultures. Second, our findings suggest to faculty and co-curricular staff in the academy that they should view their work as one of mentor to the protégé student, providing support, wisdom, challenge, and counsel. In particular, on the heels of any learning moment, students need to be able to reflect on their experiences with mentors who have been through similar rites of passage and are therefore able to share their seasoned perspective. In this vein, William James reminds us that all forms of conversion and transformation 
require "precisely the same psychological form of event—a firmness, stability, and equilibrium succeeding a period of storm and stress and inconsistency" (2002, p. 196). It is the mentor, then, who provides part of this framework of stability for the protégé who is experiencing the stress of growth and development.

There were several methodological limitations to the current study. The first of these, our small sample size for the comparisons between groups, requires that we simply gather more data in order to confirm the preliminary results we have achieved thus far. In order to generalize our findings more broadly, we recognize the importance of increasing the diversity of both the student sample and the institution from which the sample is drawn, thereby allowing us to increase demographic diversity in terms of ethnicity, religious affiliation, and parental income. Furthermore, we understand that one survey instrument, even administered longitudinally, is merely a single lens for our research investigation. Therefore, in future work, we plan to incorporate other research techniques besides survey methodology such as interviews or focus groups, in order to triangulate the findings we have observed thus far. In addition, in view of the overlap between the study abroad intervention analysis found in our work and the evidence from other researchers' work on change in faith, life purpose, and identity, we are also interested in further investigating the "why" behind the changes that occur in students who study abroad. Future research needs to examine the specific factors within the international program experience that are responsible for the positive outcomes associated with such experiences. As a signal of the continued research we hope to do, we hypothesize that there are three underlying reasons for these many changes: 1) dislocation - leaving home, 2) initiation - experiencing the differences of other cultures and seeking out mentoring and community, and 3) return - returning to the U.S. within a limited timeframe, requiring the student to assimilate their international experience into their ongoing domestic life. Finally, there was some selection bias in our two groups as those students who chose not to attend an international program scored higher on identity achievement than students who did choose to attend, when assessed during their first year of college. The groups did not differ on any other study variables during the first-year assessment period, however, supporting the idea that the international program experience was a significant contributor to group differences. Future research should, however, control for differences in identity status by incorporating appropriate comparison groups or matching procedures. Above all, as we continue to work in this area, we are encouraged by the increasing interest that students have in study abroad and the apparently significant impact that it has on their lives. 


\section{References}

Adams, G. R. (1998). Objective measure of ego identity status: A reference manual. Unpublished manuscript. (Available from the author Gerald R. Adams, College of Social and Applied Human Sciences, University of Guelph, Guelph, Ontario, Canada N1G 2W1)

Adams, G. R., Shea, J. A., \& Fitch, S. A. (1979). Toward the development of an objective assessment of ego-identity status. Journal of Adolescence, 8, 223-237.

Astin, A. W. \& Astin, H. S. (1999). Meaning and spirituality in the lives of college faculty: A study of values, authenticity, and stress. Graduate School of Education and Information Studies, Higher Education Research Institute. Los Angeles: University of California, Los Angeles.

Bryant, A.N. \& Astin, H.A. (2008). The Correlates of Spiritual Struggle during the College Years, Journal of Higher Education, 79(1).

Buechner, F. (1993). Wishful thinking. San Francisco: Harper San Francisco.

Byrd, K. R., Lear, D., \& Schwenka, S. (2000). Mysticism as a predictor of well-being. The International Journal for the Psychology of Religion, 10, 259-269.

Calvin, J. (2000). The exploration of vocation for a life of service. Baylor Horizons: Baylor University.

Campbell, J. (2003). The Hero's Journey. New World Library: Novato, California.

Crosby, P. C. (2004). Awakening the spirit: The role of higher education in leading students to discover and pursue their calling. Journal of College and Character, 2, 1-3.

Dalton, J. C. (2001) Career and calling: Finding a place for the spirit in work and the community in the implications of student spirituality for student affairs practice. New Directions for Student Service, 95, 17-26.

Damon, W., Menon, J., Bronk, K.C. (2003). The development of purpose during adolescence.

Emmons, R. A. (2005). Striving for the sacred: Personal goals, life meaning, and religion. Journal of Social Issues, 61, 731-745.

Farnham, S. G., Gill, J. P., McLean, R. T., \& Ward, S. M. (1991). Listening hearts: Discerning call in community. Harrisburg, PA: Morehouse.

Fowler, J. (1981). Stages of faith: The psychology of human development and the quest for meaning. San Francisco: Harper.

Geertz, C. (1973). The Interpretation of Cultures. New York: Basic Books.

Gonyea, R.M. (2008). The impact of study abroad on senior year engagement. Paper presented at the Association for the Study of Higher Education Annual Conference, Jacksonville, FL., November 7, 2008. 
Gonyea, R.M., Kinzie, J. Kuh, G.D., \& Nelson Laird, T.F. (2008). High impact activities: What they are, why they work, and who benefits. Paper presented at the American Association for Colleges and Universities annual meeting, Washington, DC., January 25, 2008.

Hardy, L. (1990). The fabric of this world. Michigan: Eerdmans.

Higher Education Research Institute (n.d.), College students' beliefs \& values. Retrieved March 11, 2005 from http://spirituality.ucla.edu/

Honess, K. Yardley, K., \& Yardley-Matwiejczuk, M. (1987). Self and identity: Perspectives across the lifespan. Routledge,

James, W. (2002). The varieties of religious experience. New York: Modern Library. Kass, J., Friedman, R., Leserman, J., Zuttermeister, P., \& Benson, H. (1991). Health outcomes and a new index of spiritual experience. Journal for the Scientific Study of Religion, 30, 203-212.

Kuh, G.D. (2008). High-impact educational practices. AAC\&U. Washington, D.C. Light, R.J. (2001). Making the most of college: students speak their minds. Cambridge, MA: Harvard University Press.

Liljenstolpe, E. (2008). The effect of study abroad at the Latin American studies program on conceptualization of humanity of other cultures in Caucasian university students. Paper from the website of the: Council for Christian Colleges and Universities (CCCU). Retrieved July 29, 2008 from http:// www.cccu.org/docLib/20020619_Paper\%20on\%20LASP.doc

Lindholm, J.A. (2006). The "Interior" Lives of American College Students: Preliminary Findings from a National Study. In J.L.Heft, Ed. Passing on the faith: Transforming traditions for the next generation of Jews, Christians, and Muslims. (pp. 75-102). Fordham University Press: New York, NY.

Love, P., \& Talbot, D. (1999). Defining spiritual development: A missing consideration for student affairs. NASPA Journal, 37, 361-375.

Marsden, G. M. (1992). The soul of the American university: A historical overview. In G.M. Marsden \& B.J. Longfield (Eds.), The secularization of the academy (pp. 9-45). New York: Oxford University Press.

Maslow, A. (1970). Religion, values and peak experiences. New York: Viking.

Maslow, A. (1999). Toward a psychology of being. New York: Wiley.

Meeus, W., Iedema, J., Helsen, M., \& Vollebergh, W. (1999). Patterns of adolescentidentity development: Review of literature and longitudinal analysis. Developmental Review. Volume 19, Issue 4, December 1999, Pages 419-461 .

Meilaender, G. (2000, November). Working in the horizon of God's call: Divine summons. Christian Century, 1110-1118. 
National Center for Education Statistics (2008) Enrollment in educational institutions, by level and control of institution: Selected years, 1869-70 through fall 2016. http://nces.ed.gov/programs/digest/d07/tables/dt07_ 003.asp, accessed on August 7, 2008.

Nussbaum, M. (1997). Cultivativing humanity: A classical defense of reform in liberal education. Cambridge, Massachusetts: Harvard University Press.

Obst, D., Bhandari, R., \& Witherell, S. (2007). Meeting America's global education challenge:

Current trends in U.S. study abroad \& the impact of strategic diversity initiatives. Institute of International Education: New York, NY.

Palmer, P. J. (2000). Let your life speak: Listening for the voice of vocation. San Francisco: Jossey-Bass.

Paloutzian, R. F., Richardson, J. T., \& Rambo, L. R. (1999). Religious conversion and personality change. Journal of Personality, 67, 1047-1079.

Pargament, K. I., Smith, B. W., Koenig, H. G., \& Perez, L. M. (1998). Patterns of positive and negative religious coping with major life stressors. Journal for the Scientific Study of Religion, 37, 710-724.

Raines, J. C., \& Day-Lower, D. C. (1986). Modern work and human meaning. Philadelphia, PA: Westminster Press.

Riley, N. S. (2004). God on the quad: How religious colleges and the missionary generation are changing America. New York: St. Martin's Press.

Rohr, R. (1994). The Quest for the Grail. New York: Crossroad Publishing.

Smith, C. \& Denton, M. L. (2005). Soul searching: The religious and spiritual lives of American teenagers. New York: Oxford University Press.

Stamm, L. (2004). Can we bring spirituality back to campus? Higher education's re-engagement with values and spirituality. Journal of College and Character, 2, 1-11.

Watzke, John. Language Gains During Study Abroad: A Reassessment of the "Predictors Study" and Prospects for Future Research. 32 pp. 1998. Paper presented at the Annual Meeting of the American Association of Teachers of Slavic and East European Languages (San Francisco, CA, December 1998).

Wong, P.T.P. \& Fry, P.S. (1998). The human quest for meaning: A handbook of psychological research and clinical applications. Lawrence Erlbaum Associates.

Wulff, D. M. (1997). Psychology of religion: Classic and contemporary (2nd ed.). New York: Wiley \& Sons. 
Yankelovich, D. (2005). Ferment and change: Higher education in 2015. Chronicle of Higher Education, B8.

Young, J. R. (2003). Most students care strongly about religion or spirituality, survey finds. The Chronicle of Higher Education, 1-2.

\section{A p pendix I}

Subscales and Sample Questions for the Objective Measure of Ego Identity

$$
\text { Status (OMEIS) }
$$

\section{Diffusion}

- I guess I just kind of enjoy life in general, and I don't see myself living by any particular viewpoint to life.

- I haven't chosen the occupation I really want to get into, and I'm just working at whatever is available until something better comes along.

\section{Foreclosure}

- I guess I'm pretty much like my folks when it comes to politics. I follow what they do in terms of voting and such.

- My parents' views on life are good enough for me, I don't need anything else.

\section{Moratorium}

- I'm looking for an acceptable perspective for my own "life style", but haven't really found it yet.

- There are so many different political parties and ideals. I can't decide which to follow until I figure it all out.

\section{Achievement}

- It took me a long time to decide but now I know for sure what direction to move in for a career.

- I've thought my political beliefs through and realize I can agree with some and not other aspects of what my parents believe. 


\section{Appendix I I}

\section{Subscales and Sample Questions for the Faith Attitude, Faith Experience, Vocational Calling Surveys}

\section{Subscales}

Faith Attitude Survey

Strength of Beliefs

Importance of Faith

Life Application of Faith

Spiritual Feelings

\section{Vocational Calling Survey}

Sense of Life Purpose, Calling, and Discernment

Service Toward Others

\section{Faith Experience Survey}

Religious Behavior

\section{Sample Items}

- I view myself as a religious person.

- I have doubts about whether my religious beliefs are true.

- Religion is not a very important part of my life right now.

- My faith is not very important to me.

- I depend on my faith in God for decision-making and direction.

- I try hard to carry my religious beliefs into all other dealings in my life.

- How often do you attend religious services?

- How often have you read the bible in the last year?

- Within your religious or spiritual tradition, how often do you meditate?

- I find strength and comfort in my religion or faith

- I feel God's love for me, directly or through others

- I have a well-developed understanding of what my gifts and talents are.

- I have a good sense for my purpose in life

- I plan to enter a career that emphasizes service to others.

- I feel a deep sense of responsibility for reducing pain and suffering in the world. 
